\title{
Susan Gal \\ A fogalmi metaforák elmélete és a nyelvi antropológia találkozása
}

\begin{abstract}
This paper encourages the cooperation of two subdisciplines, the study of conceptual metaphors and linguistic anthropology. In the interests if doing this, it compares the two approaches, providing two extended examples. One is an ethnographic illustration, the second is a historical example. Metaphors have pragmatic and metapragmatic forms which are worth analyzing together with conceptual ones. Kövecses's most recent book has moved in this direction, as he suggests that we interact with each other through metaphors. This study also urges more research on the social role of metaphors, as these are used and occur both in speech events and in wider politics, to balance the more usual cognitive approach.

Keywords: linguistic anthropology, pragmatic metaphor, interaction, language ideology
\end{abstract}

A metaforák fontossága az emberi életben már régóta több tudomány tárgya, melyek gyakran eltérő eredményeket mutatnak fel. Így meglepő lehet az, hogy a kognitív nyelvészetben ismeretes fogalmi metaforák elmélete és a nyelvi antropológiában közismert indexikális megközelítés igen közel állnak egymáshoz. Mindkét tudományág nyelvi adatokkal foglalkozik, noha a nyelv különböző funkcióira fordítanak figyelmet. A fogalmi metaforák elmélete leginkább a szemantikai jelenségeket kutatja, tehát a konvencionális beszéd tartalmát (denotációját) és ennek hatását vizsgálja a kognitív folyamatokra, a gondolkodásra. A módszere merít a szótárból és a tezauruszból, illetve akár a kutató intuíciójából. A híres példa erre a DÜH fogalmának metaforikus elemzése, amely szerint számos hétköznapi kifejezés alapján arra következtethetünk, hogy létezik egy olyan absztrakt fogalmi metafora, amely szerint A DÜH TARTÁLYBAN LEVÖ FORRÓ FOLYADÉK (Lakoff \& Kövecses 1987). Az adatok szerint ez az elképzelés szinte univerzális, tehát nem függ sem nyelvi, sem kulturális különbségektől. Arra is adódik példa, amikor a különböző nyelvekben a gyakori kifejezések metaforái egy-egy céltartomány esetén eltérnek, ezáltal levonható az a következtetés, hogy a fogalmi metaforák tekintetében variáció is létezik a nyelvek között. A kutató ilyenkor vizsgálhatja a különbségek döntő tényezöit, mint például a változó tapasztalati fókuszt és az összetett kontextust. Továbbá Kövecses (2006: 95) szerint: ,[a] kontextusnak lehetnek fizikai, szociális, kulturális, textuális stb. aspektusai, és olyan tényezők alkotják, mint a színtér, a téma, a hallgató és a médium, melyek mindegyike hatással lehet a metaforikus konceptualizációra". 
Susan Gal:

A fogalmi metaforák elmélete és a nyelvi antropológia találkozása

Argumentum 17 (2021), 552-561

Debreceni Egyetemi Kiadó

DOI: 10.34103/ARGUMENTUM/2021/28

A nyelvi antropológia szintén figyelmet fordít ezekre a tényezőkre, de nem ezeknek a konceptualizációra való hatását kutatja, hanem - épp ellenkezőleg - a metaforikus kifejezések hatását vizsgálja az aktuális interakcióra, szituációra vonatkozóan, emellett azt tanulmányozza, hogy a résztvevők hogyan használják a metaforikus kifejezéseket identitásuk, kapcsolataik és társas projektjeik megvalósításában és megváltoztatásában. Tehát a nyelvi antropológia nem szemantikai és denotációs kérdéseket tesz fel, hanem pragmatikai kérdéseket. Mint Jakobson (1960) korábban rámutatott, a nyelvnek több funkciója van. Minden beszédmódnak egyszerre van szemantikai és pragmatikai jelentése. Az utóbbi indexikálisan mutat arra, hogy a kifejezés milyen kontextust hoz létre vagy jelenít meg. Attól függően, hogy a résztvevők hogyan értelmezik egymás kijelentéseit, a pragmatikai jelzés meg tudja változtatni a beszélő és a hallgató identitását és kapcsolatát, valamint a szituáció definícióját és az interakció célját. Idővel a szisztematikus metaforahasználat meg tudja változtatni a (konvencionális és fogalmi) metafora jelentésfókuszát, illetve jelentését, így a metaforák aktívan vesznek részt a társadalmi folyamatok keretezésében. Emiatt a nyelvi antropológia egyszerre kutatja a nyelv információs funkcióját és társadalmi szerepét.

Amikor a metaforák pragmatikai jelentését tanulmányozzuk, akkor nemcsak a denotációt (szemantikát) vizsgáljuk - akár milyen bonyolult az -, hanem azt, hogy az a szókapcsolat, amely az interakcióban előfordul, hogyan mutat indexként egy másik szituációra, amely ugyan nincs jelen, de a kifejezés jelzi annak az adott szituációhoz füződő intertextuális kapcsolatát (Bakhtin 1981). Mindenféle nyelvi különbség hordozhat pragmatikai jelentést, mint például a következők: többnyelvü párbeszédben az egyik nyelv választása; a köznyelv használata a helyi nyelvváltozat helyett; ha több diskurzus is van, akkor az egyik diskurzus választása az adott tárgyról; hangtani és grammatikai sajátosságok. Így az intertextuális jel még denotáció nélkül is (pragmatikai) metaforát képez, egyfajta analógiát jelez vagy hoz létre a két alkalom között. De nem csak egyedi szituációkról van itt szó. Általánosabban fogalmazva, a pragmatikai metafora fogalmi kapcsolatot hoz létre az interakció-típusok között, vagy ismert (fogalmi) alkalomtípusként sorolja be az adott helyzetet. Más szóval úgy keretezi be az élőben történő interakciót, hogy az ismert eseménykategóriának számítson. Ha a fogalmi metaforában egy adott szemantikai forrástartomány elemei vetülnek rá egy adott céltartományra, akkor mondhatjuk, hogy a pragmatikai metaforában a beszélők egy társadalmilag ismert beszédesemény elemeit 'forrásként' vetítik rá az aktuális interakcióra - úgymond 'beemelik azt'. Ezáltal megváltozik az, hogy a résztvevők szerint 'mi történik', milyen esemény zajlik. A pragmatikai metafora tehát érdekes tárgya lehet a kognitív nyelvészeti kutatásoknak és különösen a fogalmi metaforák kutatásának is. Ezt jelzi Kövecses (2020) legújabb könyve is, amely azzal a megjegyzéssel zárul, hogy „,...] metaforikusan kommunikálunk egymással. Az 'interakciós fordulat' a metafora tanulmányozásában teljes (?) komplexitásában áll előttünk"1 (2020: 185).

Dolgozatomban két esetet mutatok be, ahol a pragmatikai metafora változást hoz vagy próbál hozni a társas életben, a társadalomban. Tehát itt nem az a kérdés, hogy mi határozza meg a metaforát, hanem az, hogy a metafora milyen társas kapcsolatot befolyásol. Az egyik eset etnográfiai adatokra, a másik eset pedig történeti adatokra támaszkodik. Az esetek egy hatalmi helyzet vagy konfliktusos folyamat egy-egy pillanatát példázzák. Lakoff (2002) már foglalkozott a fogalmi metaforával konfliktusos helyzetben az amerikai politikában, de ezt inkább pszichológiai, mint szociológiai vagy nyelvi antropológiai szempontból tette. Azért fontos a metafora

1 A lektor fordítása; az angol eredeti szövege: "[w]e interact metaphorically with each other. The 'interactional turn' in the study of metaphor is right before us in its full (?) complexity." 
Susan Gal:

A fogalmi metaforák elmélete és a nyelvi antropológia találkozása

Argumentum 17 (2021), 552-561

Debreceni Egyetemi Kiadó

DOI: $10.34103 /$ ARGUMENTUM/2021/28

társadalmi szerepe, mert gyakran a retorikára emlékeztet - ahogy a középkorban pozitívan definiálták: a metafora a vita és győzködés tudománya vagy annak fö technikája. Így ha el tudom érni azt, hogy a beszédpartnerem azzal az elméleti-pragmatikai metaforával - tehát abban a keretben - lássa a helyzetet, mint én, akkor meggyőztem őt, és talán áthoztam őt az én oldalamra egy kisebb-nagyobb viszályban.

\section{$1 \quad$ Az Apache kisleány}

Első példámat a nyelvi antropológia egyik klasszikusából merítem, Keith Basso hosszú távú etnográfiai tanulmányából, az Arizona őslakosairól szóló Portraits of "the Whiteman": Linguistic Play and Cultural Symbols Among the Western Apache címü könyvböl. Basso (1979) éleslátással és jó humorral írja le, hogy az Apache (apacs) férfiak - egymás közt és csak a legbizalmasabb családi közegben - hogyan gúnyolják a 'fehér embert', azt az embertípust, amely hosszú évszázadokon át elnyomó és kizsákmányoló szerepet játszott az Apache-okkal szemben. Az Apache közösség kétnyelvü és részben asszimilált. De a 'fehér ember' attitüdje az Apache-ok iránt még mindig lenéző ott, ahol a két csoport érintkezik: az angol nyelvü iskolákban, orvosoknál, üzletekben és munkahelyeken. Más kívülálló kutató ritkán hallaná az Apache férfiak vicces, de keserü paródiáját a 'fehér ember' beszédszokásairól, melyek tulajdonképpen eljátszott sztereotípiák, de Bassónak a több évtizedes terepmunka folyamán (19591979) sikerült példát gyüjtenie erről a jelenségről.

Basso a leírása szerint véletlenül lett tanúja annak a jelenetnek, amely felhívta a figyelmét arra, hogy egyáltalán létezik ilyen beszédesemény. Egy forró augusztusi délutánon, ahogy az árnyékban pihent egy fa alatt, észrevette, ahogy a szomszéd kertben egy kilencéves kisleány éppen játszott a kiskutyájával, akit (ki tudja, miért) Charles-Bronsonnak keresztelt, és megpróbálta az állatot a farkánál fogva felemelni. A kutyus tiltakozott, csaholt, és megcsípte a leányka kezét. A kutyus tette meglepte a leánykát, bár a leányka keze nem is sérült meg. A leányka mérgesen kiáltott rá a kutyusra Western Apache nyelven: „Te semmi vagy! Te semmi vagy!”, és elfordult tőle. Perceken belül pedig visszafordult, és széles mosollyal angolul szólította meg a kutyát: „Rossz vagy! - mondta élesen. - Rossz fiú! Miért csinálsz ilyet, miért okozol bajt nekem? Mindig verekedni akarsz, bajt csinálni! Most maradj itt, Charles-Bronson, nem mehetsz ki, meg vagy büntetve azért, amit csináltál! Lehet, hogy a másik tanterembe mész majd inkább. Megmondom az anyukádnak, hogy mit csináltál.” A leányka ezután megint a kutya felé nyújtotta a kezét, de az még nem békült meg, csak morogva hátrált. A leányka anyukája, aki a közelben fözött, ekkor beavatkozott: „Hagyd abba - figyelmeztette Apache nyelven -, mielőtt a kutya megint megharap!” Aztán szigorúbban hozzátette szintén Apache nyelven: „Vigyázz, mivel viccelsz! Veszélyes a fehér embert utánozni!” (Basso 1979: 10-11).

Az olvasó számára bizonyára világos a rövid történet tanulsága, amelyet Basso a könyv további, (mind felnőtt férfiakról szóló) bonyolultabb példáin keresztül részletesen elemez. Itt a nyelvváltásnál sokkal több történt, noha ez a pragmatikai metafora legnyilvánvalóbb jele. A nyelvváltás által a színtér, a beszélők identitása, a kutya és leány kapcsolata és a hatalmi helyzet mind megváltozott pillanatnyilag. A leány a beszédének megváltozott tartalmával és stílusával, amelyet Bakhtin ,társadalmi hangnak” nevezett, egy iskolai jelenetet, egy stilizált kapcsolatot játszott el a 'fehér ember' tanító és az Apache tanuló között úgy, hogy saját magára osztotta a tanító fehér ember szerepét. Ezt a stilizált kapcsolatot rávetítette az aktuális interakcióra, a kis erőszakos jelenetre a kutyával. Nagyon leegyszerüsítve a következőképp lehetne ábrázolni a 
Susan Gal:

A fogalmi metaforák elmélete és a nyelvi antropológia találkozása

Argumentum 17 (2021), 552-561

Debreceni Egyetemi Kiadó

DOI: $10.34103 /$ ARGUMENTUM/2021/28

forrástartományt - azt a feltételezést, hogy két stilizált, ellenkező Bakhtin-féle kronotópia létezik -, melyet a kisleány elöhív, és metaforaként vetít a céltartományra, azaz a kutyával való perpatvarra:

Apache nyelv - Apache ember - kert - tanulói hang/szerep - alsóbbrendủ szerep

Angol nyelv - 'fehér ember' - iskola - tanítói hang/szerep - felsőbbrendü szerep

Érdekes, hogy a sztereotipikus hatalmi kapcsolatot, amelyet a forrástartomány feltételez (tehát az aktuális társadalmi viszonyt), már jól érti egy kilencéves gyerek is. Valamilyen szinten tudja - tapasztalat vagy szállóige alapján -, hogy ez az ellentét egybeesik a tanító-tanuló párral, amelyben a tanító a szabályadó, a büntető, az autoritás - függetlenül attól, hogy ki kezdte a viszályt, és kinek van igaza.

Gondolhatnánk - és úgy tünik, az anya is azt gondolja -, hogy ebben az esetben a kutyának volt 'igaza', hiszen nem ő kezdte a konfliktust. Mindazonáltal az anya azt tanítja, hogy ezt veszélyes kifejezni, még burkoltan is. Ugyanakkor az anya megjegyzése segíti a kutatót, ugyanis az anya megnevezi - még akkor is, ha tiltja - azt az interakció-típust, amelynek a kutató a tanúja volt, mikor a kisleány beszédét hallotta: „utánozni a fehér embert”. Ezáltal az etnográfus számára világossá válik, hogy ez nem a gyerek fantáziájának szüleménye, hanem egy ismert beszédesemény a közösségen belül. Igaz, hogy itt talán kevésbé erős a gúnyolási aspektus, mint ahogy Basso később a felnőttek gyakorlatában tapasztalta.

Érdemes hangsúlyozni, hogy itt a pragmatikai metafora (a beszédtípus és a szereptípus stb. között) nem támaszkodik sem szófordulatra, sem szemantikai (denotációs) magyarázatra, amelyböl ki lehetne deríteni a (szemantikai) fogalmi metaforát. A kapcsolatok az egyik nyelv, hang, hely, szerep és hatalom között indexikálisak: metonimikus asszociációk, melyek ellentétben állnak a másik nyelvnek egy másik hang, hely, szerep és hatalmi álláshoz való indexikális kapcsolatával. Az egész fogalmi séma egy olyan előfeltételezés, amelyet az adott társadalmi közegben tanul meg az ember - ezt a nyelvi antropológia nyelvideológiának szokta nevezni (Woolard 1998). Szintén indexikális és (meta)pragmatikai az a viszony, amelyet a beszélő ezzel a sémával épít az adott beszédeseménybe. A nyelvváltással a kisleány a szituációba mintegy 'behozza' az ideológiai (fogalmi) ellentétet mint forrástartományt, és ezt rávetíti a cél tartományra, azaz az aktuális helyzetre - ezáltal indexikálisan jelez egy újonnan képzelt kapcsolatot a kutyával. Az ideológiai ellentéttel jelez - mondhatjuk, eljátszik - és így létrehoz egy új viszonyt metonímia, asszociáció, index segítségével. Azért 'metapragmatikáról' van szó, mert minden index tárgya (az, amire az index egy szituációban mutat) határozatlan addig, amíg a hallgató egyfajta keretet nem mozgósít, amely rendezi, korlátozza, hogy mi lehet az index tárgya. Ez a korlát egyfajta hallgatólagos feltétel (ideológiai elképzelés, fogalmi kapocs), amellyel együtt válik értelmezhetővé az interakció (Gal \& Irvine 2019).

Remélhetőleg a fenti példa jól szemléltette a (meta)pragmatikai metafora mivoltát. De túlzás lenne azt állítani, hogy a kisleány jelenete a kutyával megváltoztatta volna a társadalmat, vagy hogy az meggyőzési technika lett volna. (Bár ez utóbbiról a kutya véleményét is ki kellett volna kérni...) A szélesebb társadalmi hatás bizonyítására az alábbiakban egy bonyolultabb példát mutatok be a saját kutatásaim eredményéből (Gal 2013, 2018: 79-100). 
Susan Gal:

A fogalmi metaforák elmélete és a nyelvi antropológia találkozása

Argumentum 17 (2021), 552-561

Debreceni Egyetemi Kiadó

DOI: $10.34103 /$ ARGUMENTUM/2021/28

\section{A magyar géniusz}

Az Apache kisleány esete jól szemléltette az Apache és az angol nyelv közti rangkülönbséget vagy legalábbis a 'fehér ember' elképzeléseit erről, de arról nem szolgáltat adatot, hogy a beszélők milyen jellegzetességbeli különbségeket véltek fontosnak a két nyelv között, és miért. Pedig a nyelvideológiáknak az a gyakori tulajdonsága, hogy megpróbálják indokolni - sőt racionalizálni - a csoportok közti társadalmi-hatalmi különbségeket a nyelvek vélt differenciái vagy - mint az alábbi esetben, ahol csak egy nyelvröl van szó - a nyelvileg megkülönböztethető diskurzusok alapján (Gal 2018: 101-128). Ezzel kapcsolatban persze gyakran alakul ki vita, sőt akár küzdelem is. Ekkor nyerhet kulcsfontosságot a pragmatikai metafora mint a meggyőzés technikája. A 19. századi Magyarországon is volt erre egy igen szemléletes példa.

A 19. század végén nagy elismertségnek örvendett Rákosi Jenő (1842-1929) mint újságíró, költő, publicista. Sok témáról írt, de kedvenc tárgya a magyar nyelv volt. Német nyelvű családba született, és német nyelvü iskolába járt serdülőkoráig, amikor is találkozott azzal a magyar nyelvi nacionalizmussal, amely éppen akkor, az 1867-es kiegyezés idején, óriási népszerüséget nyert még a magyarországi kisebbségek között is (melyek az ország akkori lakosságának nagy részét alkották) - legalábbis azoknál, akik felfelé vágytak a társadalomban (Sajó 1930). A kiegyezés után megszünt a bécsi cenzúra és az elnyomás, amelyet az osztrák állam a 1848-as szabadságharc leverése után gyakorolt a magyar kulturális élet ellen. A német nyelv hegemóniája és a többnyelvűség korábbi értéke erősen csökkent (Gal 2011). Nyitott kérdés volt, hogy Magyarország mennyire lesz alárendelt a Monarchiában, és mi a helyes viselkedés Ausztriával szemben. Egyúttal megnyíltak a mobilitás lehetôségei a tehetséges fiatal értelmiségiek számára, akik foglalkozni kívántak az akkor aránylag elhanyagolt magyar nyelv, müvészet és kultúra témáival. Talán épp ez vált vonzóvá a kisebbségi fiatalok számára, hisz az ő asszimilációjuk, az ő magyar nyelv iránti lojalitásuk politikailag fontos lett (Gyurgyák 2007).

Rákosi amatőr nyelvészként írt, mindig magyarul. Népszerüsítette a Deák-féle kiegyezési párt véleményeit a Pesti Naplóban, mely politikai napilap épp ennek az irányzatnak volt a szóvivője. Tárcáiban az új, felfelé törekvő középosztályt szólította meg. „A nyelv kultusza” (1914 [1882]) címü cikkében azt állítja: „Tudjuk, hogy nagy civilizációk gőgös katonái lenézik és szívesen becsmérlik a magyar nyelvet. Szegények, nem tudják, miről beszélnek” (21). Buzdítóan írt a (képzelt) sértés ellen tiltakozva, megmutatva miben téved a világ. Igaz, kezdi, hogy rossz állapotban van a nemzet, mert ,az idők viszontagságai megfosztották mindentől, amit keletkezése óta létrehozott, vagy gonosz körülmények megakadályozták mindannak a létrehozásában, amire különben képes lett volna" (15). De mindez nem vészes, mert ha megvan a nyelv, a nemzet újra „diadalra juttathatja nemzeti karakterét és újra megalkothatja nemzeti civilizációját" (15). Ezzel a jóslattal Rákosi nagyobb feladatot vállal, minthogy aláírja a régi európai alapelvet, mely szerint „nyelvében él a nemzet”. Inkább le akarja írni, igazából milyen ez a lenézett nyelv, hogyan képes ilyen nagy tettre (1914 [1882]: 16, kiemelés a Szerzőtől):

A legtisztább, legeredetibb, leglogikusabb és legérdekesebb nyelv Európában a magyar. Mindezt szerkezetére és törvényeire nézve értem. Hozzátehetem, hogy nyilván eredetére nézve is a legrégibb. Az összes európai nyelvek... atyafiságban vannak egymással. Közös eredetük kimutatható. Egy sincs azonban köztük, mely szerkezetében oly egységes és kizárólagos volna, mint a magyar. A legegyszerübb eszközökkel éri el a legfőbb célokat, amelyeket a nyelv szolgál. És ha elemezzük, elemei közt ugyanazokat a jellemzö tulajdonságokat, sajátságokat és törvényeket találjuk, melyeket magában a magyar emberben és környezetében. 
Susan Gal:

A fogalmi metaforák elmélete és a nyelvi antropológia találkozása

Argumentum 17 (2021), 552-561

Debreceni Egyetemi Kiadó

DOI: 10.34103/ARGUMENTUM/2021/28

Tehát Rákosi egy nagy metaforasorozatot képez, amely szerint a nyelv tulajdonságai egyenlőek a beszélő tulajdonságaival. A minőségük egyforma. Számára magától értetődő, hogy aki magyar ember, az magyarul beszél. A nagyobb kérdés, hogy miféle ember lesz abból, aki magyarul beszél. Ez azért fontos, mert egyúttal sürgeti az asszimilációt (1914 [1882]: 16):

[A] mi nemzeti géniuszunk jobban, elevenen munkál abban az idegen bevándorolt házaspár gyermekében, aki kizárólag a magyar nyelvben nőtt emberré, mint abban az ősi családból eredt magyar úrban, aki idegen nyelveken szedte magába müveltségét.

A cikk nagy része a nyelv és a beszélő kapcsolatával foglalkozik, közelebbről azzal, hogy az egyik miként tükrözi a másikat. Több nyelvről (német, francia, olasz) és annak környezetéről van szó, mert összehasonlító a módszer. Az alábbiakban a német nyelvet emelem ki a magyarhoz viszonyítva (1914 [1882]: 17):

És ki nem ismeri a gót stílust és az ónémet házépítést, a maga tornyocskáival, fülkéivel, erkélyeivel, kiugrásaival... és százféle tagoltságaival! És ki ne tudná, hogy a német... épp úgy beszél, mint ahogy épít, ide-oda szökő hangsúllyal, elnyalt s elharapott szótagokkal, a magánhangzók kétségbeejtő variációival, a mássalhangzók hihetetlen elköszörülésével... [M] egvan a nyelv karaktere magán az emberen is: .... a német nehézkessége és pátosza nyelvéből ered. ...[K]ell hozzá... gesztikulálni, szinte hadonázni, sőt arcokat vágni.

A magyar nyelv a magyar paraszt építkezésének felel meg, de egész más - szinte ellenkező tulajdonságokkal, mint a német (1914 [1882]: 19):

\footnotetext{
És nézzék meg a magyar nyelvet..., amely nem cifrázza magát hangsúlyokkal, épp oly kevéssé, mint az ember beszédét gesztikulációval; hanem mint ahogy a [paraszti] lakóházrész elől van, azután hozzárovódnak a más célokra szükséges részek - megüti az első szót és sorakoztatja méltóságos tempóban a többit. És nem kever egymáshoz nem illő magánhangzókat, hanem vonzatja hangtörvénye szerint a felhangúakat felhangúval, az alhangúakat az alhangúval. ...

És ha egymáshoz viszonyba hozza a szókat, ...egyszerü ragozással teszi, nem töri át a szót, hogy ich magból ich möcht-et csináljon, hanem elül ereszti a szót magát..., azután hozzátoldja a ragot, mint a házához a mellékhelyiségeket...

E nyelv nyugodt, méltóságos, ünnepies struktúrájában megvan a magyar paraszt megfontolt, önérzetes jelleme, egész megjelenése.
}

Talán a mai nyelvész egy kicsit elmosolyodik Rákosi elemzését olvasva. De ő nem viccelt, és - legalábbis a nyelv vonásait illetően - nem tévedett. Amit leírt a magyar (és a német) nyelvről, ma is elfogadott tény. Meglepő viszont az a következtetés, amelyet a nyelvek fonológiai és nyelvtani tulajdonságaiból vont le. Az egyenlet a nyelv és a (tipizált) beszélő jellegzetességei között jobban ismerős lehet a kultúrtörténészeknek. Ez a 19. századi páneurópai herderiánus nemzetfelfogás, amely világszerte elterjedt, és talán most is él enyhébb verzióban. Milyen is eszerint a magyar embertípus képe harminc évvel a véres forradalmi szabadságharc után? Rákosi szerint a magyar ember - beleértve a parasztembert is, de nem csak öt - nyugodt, méltóságos, egyszerü és nem cifra, illetve egységes, szabálykövető és törvénybetartó, nem 'tör át' másokon (értsd: nem erőszakos).

Rákosi a nagyszabású metaforájának struktúrájában a fogalmi metaforák elmélete és a nyelvi antropológia szerint is a nyelvet használja forrástartományként, és ezzel térképezi fel a céltartományt, azaz a magyar ember képzelt vonásait. A nyelvi antropológia azt is hangsúlyozná, hogy ez a metafora csak abban a nyelvideológiai keretben érvényes, amely szerint a nyelvek indexikálisan jelzik a beszélö nemzetét vagy másféle társadalmi csoportját. Ez nem univerzális, 
Susan Gal:

A fogalmi metaforák elmélete és a nyelvi antropológia találkozása

Argumentum 17 (2021), 552-561

Debreceni Egyetemi Kiadó

DOI: $10.34103 /$ ARGUMENTUM/2021/28

de gyakori ideológia, és megfelel annak a kapcsolatnak, amelyet az Apache-oknál is láttunk, ahol a nyelvi különbség jelezte a csoport, a hely és a szerep kiosztási különbségét.

Emellett a nyelvi antropológiában a tulajdonságok egyeztetése a nyelv és az embertípus (sztereotípia) között külön figyelmet kap, mert ez már nemcsak indexikális (mutató), hanem ikonikus (ábrázoló) kapcsolat is. A kapcsolat egyben fogalmi és (meta)pragmatikai kérdés is. Fogalmi sztereotípia kapcsolja össze a nyelvet a beszélöjével. Élő interakcióban tapasztaljuk az asszociációt a beszélő és a nyelv között, amelyből ered, vagy amelyben megnyilvánul az indexikális (metonimikus) kapcsolat és annak fogalma. De a hallgató/résztvevő ikonná válthatja az indexikális jelet, ha az értelmezésében egy további szemiotikai müveletet is igénybe vesz. Ehhez (ideológiai) alátámasztó felfogások szükségesek. Ez látszik Rákosinál, aki azt írja, hogy a magyar „nemzeti géniusz inkarnációja a nemzeti nyelv”, amely „élő és szerves képe magának a nemzetnek: gondolkozásának, alkotásainak, filozófiájának, politikai észjárásának és egész jellemének" (1914 [1882]: 16). Tehát az adott nemzet géniusza az a láthatatlan erő, amelynek megtestesülése a nemzet összes termékében hasonlóságot teremt. Ezért fontos Rákosinak az építkezési szokások sajátosságait a nyelv tulajdonságai mellé állítani és a hasonlóságokat kiemelni. Ez erős bizonyítéknak számít. Azonban minden nyelvnek számtalan tulajdonsága van, amelyek közül csak az adott érvelés szerint tudunk választani, például összehasonlítás céljából.

De Rákosi cikke nem egyszerü leíró vagy összehasonlító nyelvészeti elemzés, mint ahogy talán felületes olvasásra tünik. Mi igazából a cikk műfaja? Érdemes rákérdezni arra is, hogyan illeszkedik a nyelv és a nemzet kapcsolatával foglalkozó írások közé, amelyek oly gyakoriak voltak a kiegyezés utáni évtizedekben. Ne csak azt kérdezzük, hogy mi okozta ezt a kiterjedt fogalmimetafora-sorozatot! Kérdezzük meg azt is, hogy mi annak a diskurzusnak a társadalmi szerepe, amely arra biztat, amit Rákosi előad? Itt ugyanis nem egyszerüen a nyelvtudomány álláspontjáról vagy Rákosi személyes véleményéről van szó.

A nyelvi antropológia, Bakhtint követve, úgy érvel, hogy minden kifejezés - legyen akár írott, akár szóbeli - egyfajta választ ad egy korábbi kijelentésre vagy gyakori feltételezésre. $\mathrm{E}$ szerint a megközelítés szerint Rákosi írása egy virtuális (hallgatólagos) párbeszédben vesz részt. Amikor például kijelenti, hogy a „magyar szónoklati remek” az, aminek ,gyönyörü nyugalma... és realitása" van, és ez megfelel a „nyelv szellemének” (20), amely egyet jelent a nemzet szellemével, akkor arra biztat, hogy a nyelv maga ad bizonyítékot a nemzet békés megbízhatóságáról. Ahogy az Apache kisleány is 'beemelt' egy másik színteret a kutyával való interakciójába, amelyben a tanító szerepét vette át, úgy Rákosi is beemel az értekezésébe valamit a magyar nemzet mivoltáról szóló szélesebb országos vitából és az e szerinti helyes politikáról. Sőt mi több, Rákosi azt a szerepet vállalja ebben az országos párbeszédben, amely azt hirdeti, hogy a nyelv látszólag objektív és nyilvánvaló vonásai igazolják, legitimálják, sőt ábrázolják is a nemzet nyugodt és reális természetét. Sőt, ezek a tulajdonságok olyan tények, amelyeket mindenki a saját szemével és fülével tapasztalhat. Ez talán meglepte azokat, akik megélték az 1870-1880-as évek utcai tüntetéseit és kisebbségi konfliktusait.

Más diskurzust, más Bakhtin-féle hangot hallunk viszont Jókai Mórtól (1825-1904) a négy évvel korábban (1878) kiadott egyik röpiratában. Rákosihoz hasonlóan Jókai is elismeri a nyelv szépségét és tökéletességét, valamint ő is nyelvi adatokra hivatkozva ért egyet azzal a nyelvideológiai nézettel, hogy a nemzet karakterét a nyelvben fedezhetjük fel. Jókai viszont nem fonológiai és nyelvtani, hanem lexikai jelenségekre támaszkodik. Feltünő, hogy nem a nyugodt, nyugalmas és méltóságos, békés és realitást látó diskurzus jut eszébe. Épp ellenkezőleg: a híres író és politikus, aki fontos szerepet játszott a szabadságharcban, a saját nemzetét bírálja, és 
Susan Gal:

A fogalmi metaforák elmélete és a nyelvi antropológia találkozása

Argumentum 17 (2021), 552-561

Debreceni Egyetemi Kiadó

DOI: 10.34103/ARGUMENTUM/2021/28

fellép a Függetlenségi Párt ellen. Rámutat, hogy a párt háborús javaslatának katasztrofális eredménye lett volna (1878: 39):

Igen, de meg lett volna a dicsőségünk.

No - ez a szó az, a min hajótörést szenved minden magyar államférfi.

Mert a ki azt mondja a magyarnak, »kicsiny nemzet vagy, sok az ellenséged: ápold a nemzetiségedet csendesen..., « az hazaáruló! azt megkövezzük. Hanem a ki azt mondja neki: »ne félj semmit, izenj háborút az egész világnak, megbírod te azt...!« az félistenünk lesz, azt vállainkra emeljük.

Jókai tíz évvel később (1888) tovább folytatja ezt a diskurzust, amikor egy nagy etnográfiai leírást publikál Rudolf főherceg, a szabadelvủ trónörökös által szervezett óriási népenciklopédiában (a Kronprinzenwerkben). Itt ismét nyelvi adatokra - nyelvhasználati szokásokra hivatkozik. Bemutatja, hogy a magyar nép „kedélye” és ,véralkata” kevert: „vérmes, flegmás és méla... Könnyen felindúl, de könnyen kibékül”. Kiemeli, hogy ,a magyar faj harczi modora” és bizakodása - amelyről több szólásmondást is felhoz példaként - a „büszkeségének is az alapja; elsőbbséget maga fölött semmi más nemzetnek nem ád”. Továbbá a következőket is hangsúlyozza (1888: 296):

Hajdan... a magyar nemes a világ legbüszkébb emberének vallotta magát; azonban még a parasztja is aristocrata volt, és ma is az nem csak más fajok, de egymás között is, és alig van egyebütt annyi fokozat a megszólításokban, mint a magyarnál: kend, kegyelmed, ifju uram, nagy uram, nemzetes úr, tekintetes úr, nagyságos, ... kegyelmes; tiszteletes, tisztelendő, nagytiszteletü... úr; s a ki ezek közül egyet elcserél, haragot von a fejére.

Jókai itt a beszélőtípus tulajdonságát a nyelvhasználatból vonja le, az elemzése indexikális és ikonikus jeleket feltételez - csakúgy, mint Rákosi, de egész más eredménnyel. Egységességről nincs szó, ahogy egyszerűségről sincs, amely mellőzné a cifraságot. Épp ellenkezőleg: a fő elem ebben a diskurzusban a hierarchia és annak kidolgozása a nyelvhasználati szokásokban. Jókai nem kevésbé vitatkozik, mint Rákosi - de az egyik a romantika ('géniusz'), a másik a realizmus ('alkat') stílusában teszi ezt. Sőt, Rákosi diskurzusát lehet (burkolt) válaszként is értelmezni arra a (talán akkoriban híresebb) nemzetdiskurzusra nézve, amelyet Jókai hangoztat és kritizál, s amelynek kritikája az ő mérsékelt szabadelvü politikai hovatartozását jelzi.

Nem az a lényeg tehát, hogy az egyik vagy a másik nemzetkép állt-e közelebb az akkori valósághoz. Mindkét koncepció idealizált kép volt. Az ilyen sztereotípiák sosem tükrözik hủen a valóságot. A társadalmi szerepük inkább az, hogy elősegítsék a meggyőzést egy adott ügyben vagy döntésben. A nagy politikai kérdések a csorbított önkormányozásról, az állam (át)szervezéséről és a kisebbségiekkel való együttélésről szóltak. Míg Rákosi a jó uralkodási képességre próbált rámutatni, Jókai a veszélyekre mutatott rá. Mindketten nyelvi adatokra támaszkodtak, amikor szerepet vállaltak az egymással ütköző országos diskurzusokban. Aki nem a nyelvideológia és nem a fogalmi metaforák szempontjából közelíti meg az akkori írók nyelvleírásait, annak nehéz megérteni, hogy a nyelv hangtanának vagy a beszélők megszólítási szokásainak mi köze van a mindennapi gazdasági, külpolitikai és hatalmi döntésekhez, amelyekkel a magyarországi vezető rétegek küzdöttek. A vitákban hatalmas kérdés volt a nemzet karaktere mint jogosítás bármilyen politikai döntésben. Ironikus módon az írók a magyar nyelv látszólagosan objektív tulajdonságait használták fel két nagyon eltérő nemzetkép igazolására és legitimálására, s ezzel nemcsak a saját pártpolitikai hovatartozásukat, hanem azt a szándékukat is jelezték, hogy (elméleti és metapragmatikai) metaforákkal győzzék meg az olvasóközönséget. 


\section{$3 \quad$ Konklúzió}

E cikkben azt igyekeztem bemutatni, hogy a fogalmi metaforák elméletének legfrissebb változata, amelyről Kövecses Zoltán (2020) oly meggyőzően ír, közeli kapcsolatba hozható a nyelvi antropológia alapelveivel. Ez a konvergencia termékeny elmélethez és elemzési módszerhez vezethet. Reddy (1979) már rég felhívta a figyelmünket arra, hogy - a fogalmi metaforáinkkal ellentétben - a nyelv nemcsak az eszménkben és fogalomként él, hanem az emberi interakciókban is.

Tanulmányom nemcsak fogalmi, hanem (meta)pragmatikai metaforákról is szólt - azokról, amelyek összekapcsolják a beszélőt a diskurzusával és az interakciós kontextusával az indexikális és ikonikus jelek segítségével. Ezeket a jeleket nyelvideológiai elméletek definiálják és korlátozzák. Érvelésem szerint nemcsak azt a fontos kérdést érdemes vizsgálni, hogy mi határozza meg a fogalmi metaforákat - így például a forrástartomány és céltartomány viszonyát -, hanem azt is, hogy a metaforák milyen hatással bírnak a társas életben, hogyan tudják befolyásolni a beszélő identitását és kapcsolatait, illetve megvalósítani céljait, továbbá hogy nagyobb társadalmi vitákban hogyan töltenek be fontos funkciót. Ezeket a lehetőségeket két rövid példával próbáltam szemléltetni. Az első egy jelenet volt Basso híres Apache etnográfiájából, mely egy kisleány interakcióját elemzi. A másik pedig két 19. századi magyar író véleménye volt arról, hogy milyen a magyar nemzet karaktere. Bár véleményeik ellentmondanak egymásnak, mindketten a nyelvre vonatkozó metaforákra támaszkodnak, hogy igazolják az országban elterjedt éles vita egyik, illetve másik oldalát. Céljuk tehát az olvasóközönség meggyőzése. Példáimnak az a lényege, hogy a fogalmi és metapragmatikai metaforák együtt központi és aktív szerepet játszanak a társadalomban.

\section{Irodalom}

Bakhtin, M. M. (1981): The Dialogic Imagination: Four Essays. Austin: University of Texas Press.

Basso, K. (1979): Portraits of the "Whiteman": Linguistic Play and Cultural Symbols Among the Western Apache. New York: Cambridge University Press. https://doi.org/10.1017/CBO9780511618147

Gal, S. (2011): Polyglot nationalism: Alternative perspectives on language in 19th century Hungary. Langage et société 136, 31-53. https://doi.org/10.3917/ls.136.0031

Gal, S. (2013): Tastes of talk: Qualia and the moral flavor of signs. Anthropological Theory 13.1-2, 31-48. https://doi.org/10.1177/1463499613483396

Gal, S. (2018): A nyelv politikája: Nyelvi antropológiai tanulmányok. Nyitra: Nyitrai Konstantin Filozófus Egyetem Közép-európai Tanulmányok Kara.

Gal, S. \& Irvine, J. T. (2019): Signs of Difference: Language and Ideology in Social Life. UK: Cambridge University Press. https://doi.org/10.1017/9781108649209

Gyurgyák, J. (2007): Ezzé lett magyar hazátok: A magyar nemzeteszme és nacionalizmus története. Budapest: Osiris.

Jakobson, R. (1960): Closing statement: Linguistics and poetics. In: Sebeok, T. (ed.): Style in Language. Cambridge, MA: The MIT Press, 350-377.

Jókai, M. (1878): Mondjuk ki az igazat. Budapest: Az Athenaeum R. Társulat Könyvnyomdája. 
Jókai, M. (1888): A magyar nép (A magyar nyelv sajátságai; A magyar nép kedélye, véralkata). In: Az Osztrák-Magyar Monarchia irásban és képben. 1. kötet. Budapest: Magyar Királyi Államnyomda, 279-298.

Kövecses, Z. (2006): A fogalmi metaforák elmélete és az elmélet kritikája. Világosság 8-9-10, 87-97.

Kövecses, Z. (2020): Extended Conceptual Metaphor Theory. Cambridge: Cambridge University Press.

Lakoff, G. (2002): Moral Politics: How Liberals and Conservatives Think. Chicago: The University of Chicago Press. https://doi.org/10.7208/chicago/9780226471006.001.0001

Lakoff, G. \& Kövecses, Z. (1987): The cognitive model of anger inherent in American English. In: Holland, D. \& Quinn, N. (eds.): Cultural Models in Language and Thought. Cambridge: Cambridge University Press, 195-221. https://doi.org/10.1017/CBO9780511607660.009

Rákosi, J. (1914 [1882]): A nyelv kultusza. In: Rákosi, J.: A Magyarságért. Budapest: Élet, 14 22.

Reddy, M. (1979): The conduit metaphor: A case of frame conflict in our language about language. In: Ortony, A. (ed.): Metaphor and Thought. Cambridge: Cambridge University Press, 284-324.

Sajó, A. (1930): Rákosi Jenő életpályája. In: Süle, A. (szerk.): Rákosi Jenő élete és müvei. Budapest: Fővárosi Könyvkiadó, 19-117.

Woolard, K. (1998): Introduction: Language ideology as a field of inquiry. In: Schieffelin, B., Woolard, K. \& Kroskrity, P. (eds.): Language Ideologies: Practice and Theory. Oxford: Oxford University Press, 3-50.

\author{
Susan Gal \\ Distinguished Service Professor of Anthropology and Linguistics \\ University of Chicago \\ 1126 East 59th Street \\ Chicago IL 60637 USA \\ susangal@uchicago.edu
}

